\title{
Network Centrality and Homophily in Stakeholder Relationship Management: The Effects on a Social Enterprise's Decision-Making Process
}

\author{
Ornella Papaluca ${ }^{1,2} \&$ Mario Tani ${ }^{2}$ \\ 1 Stazione Zoologica Anton Dohrn, National Institute of Marine Biology, Ecology and Biotechnology, Villa \\ Comunale 1 - 80121 - Naples, Italy \\ 2 Department of Economics, Management, Institutions, University of Naples Federico II, Naples, Italy \\ Correspondence: Ornella Papaluca, Stazione Zoologica Anton Dohrn, National Institute of Marine Biology, \\ Ecology and Biotechnology, Villa Comunale, Naples, Italy. E-mail: ornella.papaluca@unina.it
}

Received: December 29, 2019

Accepted: January 16, 2020

Online Published: January 19, 2020

doi:10.5539/ijbm.v15n2p123

URL: https://doi.org/10.5539/ijbm.v15n2p123

\begin{abstract}
Managing relationships with all the stakeholders is a central issue in Social Enterprises' management; these enterprises, operating across the faded boundary between for profit and not for profit sectors, overcome having limit scarce resources dotation trough relationships with other organizations in order to reach success in the society.

In our paper, we have studied the capability of this class of enterprises to create and sustain relationships on the basis of the concepts and principles of Stakeholder Theory, that according enterprises' survival capacity is linked to their manage ability those actors that affects or are affected by enterprise actions in their decision-making. Our empirical studies have focused on the social network, defined trough a snowballing process (degree $=3$ ), insisting on a Social Cooperative in Naples with two world shops and one wholesale warehouse.

Each node in the Social Cooperative's egonetwork has been tested for two classical measures of Social Network Analysis (Wasserman \& Faust, 1994; Scott, 1991): centrality and proximity. These tests have been later used to compare actors and to analyze if more central or more homophilous actors, those who share similar interests, are better able to influence the social cooperative.

Our paper highlights that homophily can better explain stakeholders' effects on the outcomes of strategic decision-making processes.
\end{abstract}

Keywords: Fair-Trade organization, social enterprises, social network analysis, stakeholder management, strategy definition

\section{Introduction}

\subsection{Background of the Problem}

Modern business can be seen as complex system, unstable and mutable, in which the players are usually forced to create, sustain and develop a great number of heterogeneous relationships with other classes of actors operating in the external environment. These players usually depend on these relationships to get access to several meaningful resources needed to carry on their day to day operations (Pfeffer \& Salancik, 1978), to survive in the business and to obtain a sustainable competitive advantage (Dyer \& Singh, 1998; Gulati, 1998; Sciarelli, Tani, Landi \& Papaluca, 2019). Infact, these players are able to aid, or to hinder, management processes in defining the strategies of the organisations engaged in these relationships and needed to reach, and sustain, a position of competitive advantage (Barney, 2007). The outcome of these continuous interactions have been studied both as a direct impact on firm's strategic processes (Freeman, 1984) and as an indirect one, mainly focusing on the network of relationships each single enterprise lives into (Pfeffer \& Salancik, 1978; Shapiro, 1988; Dyer \& Singh, 1998).

In order to overcome the so called separation fallacy (Freeman, Harrison, Wicks, Parmar \& De Colle, 2010) between business and ethical decisions management has to acknowledge the complex set of factors driving human evaluations and each manager have to learn how to consider all the relevant different interests while 
building enterprise's strategies on behaviors explicitly oriented to those same set of values for helping the organization in surviving in the specific environment it insists on.

The urge to broaden conventional enterprise's responsibilities to encompass more "social" aspects is hindered by management's need to acknowledge a higher priority to economic interests (Drucker, 1974; Langtry, 2015), but there is subject that should be naturally less inclined to fall in the "separation fallacy" trap: social enterprises (Borzaga \& Defourny, 2001; Defourny \& Nyssens, 2008; Yunus, 2008).

Social Enterprises are market players that naturally have to pursue survival, even trough economical sustainability, while accomplishing an explicit social mission to create direct positive effects in a given community or to aid a specific class of social actors usually neglected by conventional enterprises (Smith, Besharov, Wessels, \& Chertok, 2012).

Relationship management is one of the main competences in modern enterprises (Dyer \& Singh, 1998) and the same holds for Social Enterprises as their stakeholders (Freeman, 1984) can more easily influence its behavior linking its chances to be "successful" to their capability in acknowledging and satisfying social environment's needs and to embed them in their "social mission".

\subsection{Prior Literature}

Management of relationships between an organization and other entities has become a focal point in strategic management studies as stable, fruitful relationships are considered to be an effective way to improve a firm competitiveness and, at the same time, a great source of risks and dangers to enterprise survival (Day, 1994, 1999; Dyer \& Singh, 1998; Barney, 2007).

This more central role given to relationship management is more visible as new information and communication technologies help actors to increase contacts' frequency between them, with the side effect to reduce that uncertainty it was usually considered as a hindrance to smooth management decision processes (Lin, 1999; Kilduff \& Tsai, 2003; Brady \& Haugh, 2011); on the other side it has been also highlighted as these same factors can limit freedom of managerial action (Borgatti \& Foster, 2003).

Some authors (Fombrun, 1982; Rowley, 1997) have highlighted that enterprises have to manage each single relationship taking into account its interactions with the whole relationships network and those interests the network is built upon (Freeman \& Evan, 1990; Wasserman \& Galaskiewicz, 1994).

These considerations outline a vision of a company immersed in a web of complex stable and mutually influencing relationships (Sydow \& Windeler, 1998) binding managerial behaviors to stakeholders' expectations (Rowley, 1997).

This view, usually referred to as stakeholder management (Freeman 1984; Donaldson \& Preston, 1995), differs from Contingency Theory (Burns \& Stalker, 1961) and Industrial Economics (Porter, 1980) as it is not focused on a generic set of relationships between the company and a not clearly defined "External Environment" or, maybe, only some generic classes of its actors, but it focuses on the links created between a well-defined sub-set of social actors: the enterprise and its own stakeholders.

There are several definitions of this term in literature (Hinna, 2002) but Logdson and Lewellyn (2000) have found out that the original definition still holds its ground and it is widely used (Freeman, 1984, p. 46):

\section{A stakeholder in an organization is (by definition) any group or individual who can affect or is affected by the achievement of the organization's objectives.}

The focus on managing these relationships and on evaluating the effects of organization's strategy with a broader scope helps this theory (Freeman, Harrison, Wicks, Parmar, \& De Colle, 2010) to address many of the concerns identified as important in the strategic management field without recurring to reinstate the separation fallacy i.e. that business and social decisions have to be separated (Ansoff, 1965) and enterprises must consider the latter only as problems of lesser importance that can be addressed when they help enterprise's competitive success or, at least, do not hinder it. Relaying on this fallacy imply that managerial decisions can be considered as a simple trade-off between alternatives without addressing the decision-making issue of concurrent alternative evaluations criteria (Drucker, 1974) and changing trade-offs between values.

Since early contributions of stakeholder management theory, the very same concept of stakeholder become the foundation for a new theory of the firm (Donaldson \& Preston, 1995; Rowley, 1997) that asks managers to "create as much value as possible for stakeholders, without resorting to trade-offs" (Freeman, Harrison, Wicks, Parmar \& De Colle, 2010, p. 28).

Research efforts in this stream aim to define stakeholders' characteristics (Donaldson \& Preston, 1995; Hinna, 
2002) and to design decision making tools to classify them into homogeneous classes (Mitchell, Agle \& Wood, 1997) in order to understand them and help in defining policies for their management (Rowley \& Moldoveanu, 2003) and for helping their active participation in the operation of the organization (Dill, 1975).

One of the main issues in managing stakeholder's relationships is strategy definition when there are conflicting interests held by competing actors in the same network; in this scenario managers will be able to satisfy only some stakeholders requests, needs, but must accomplish that without upsetting any other one (Daft, 1998) in order to avoid unsatisfied stakeholders reaction of using their own resources to hinder enterprise actions or, in the most favorable case, to put pressure on it making them more difficult (Savage, Nix, Whitehead \& Blair, 1991; Frooman, 1999; 2010).

A general need of choosing among different stakeholders is addressed by Mitchell, Agle and Woods (1997) when they define three common criteria to follow in order to identify the most important actors for a given organization in a given moment: legitimacy, power of the social actor and urgency of the interest protected. A similar approach is the one developed by Kochan and Rubinstein (2000) in defining a stakeholder's saliency as a function of his ability to provide valuable resources for the enterprise, to hinder retrieval of valuable resources from other sources and, in general, of the influence a given stakeholder has inside the organization.

A different approach in solving this focal issue has been proposed by Rowley (2000); the scholar proposes not to focus on the single individual stakeholders but to try to consider the whole structure of the relationships network among them and to utilize the typical tools of the Social Network Analysis to define a path of best actions for the company's management or, at least, to help them in decision making processes.

Social Network Analysis is a theory and a set of tools to study networks originating in the fifties (Tichy, Tushman \& Fombrun, 1979; Scott, 1991); it is getting ever more popular (Borgatti \& Foster, 2003) even if it often used only as a tool to support other theories (Galaskiewicz, 1996), so that it is often considered as merely a collection of tools to analyze data (Borgatti, 2005).

Social Network Analysis has become widespread thanks to its ability to study together micro and macro phenomena and to help explain how they are linked to organization behavior (Tichy, Tushman \& Fombrun, 1979); another reason given for its diffusion is its own effectiveness in representing social networks starting from relational attributes of social actors. Other authors have pointed out that Social Network Analysis cannot help reach significant results when research focus is on the creation, the evolution or the development dynamics of a network (Emirbayer \& Goodwin, 1994; Watts 1999); Watts (2004) counters these considerations highlighting that they are only a consequence of how research has been carried on using these tools but this is not due to one of their intrinsic limitations.

Development of the theory behind this approach to network analysis can been divided into three main streams: the first one is labeled as the structuralist approach as it focuses on individual actors position in the network (Granovetter, 1973; Kilduff \& Krackhardt, 2017; Rowley, 2000), the second one, called connectionist approach, links actor's power in the network to his own ability to exploit relationships in order to get control of needed, heterogeneous, resources flows (Dyer \& Singh, 1998; Lin, 1999), and finally there is Burt's approach (1992) based upon the concept of structural holes, this approach states that a person is more influential if he succeed in occupying a central position in the network as in those positions he can rule over resources flows affecting a broader part of the network. Some authors consider Burt's approach as a structuralist one (Lin, 1999; Borgatti \& Foster, 2003) as in his theory network's configuration, its structure, and the specific location of a given actor in the specific network are all factors far more important than the specific resources flowing traveling through the relationships.

Using Social Network Analysis' tools, a researcher can represent all the links between stakeholders and between them and a given enterprise; moreover, they can be used to analyze relational characteristics each actor has in a specific network. The first of these characteristics is the centrality, a measure expressing how much the subject is active within network itself (Shaw, 1954; Freeman, 1977). This measure if combined with the concept of network density (Watts, 2004), allows researchers and managers to evaluate how many of the resources flows within the network, or even only a part of it, depends on the presence of the individual; indirectly they can be used to assess how much the network would be damaged if the players would decide to cut all of its relationships, as for when an organization leaves a network to enter another one (Watts, 1999).

A second characteristic is the proximity of a given subject to all the other ones in the network (Fombrun, 1982; Wasserman \& Faust, 1994), it can help to measure, or at least understand, how quickly a person can convey informations in the network. Closely related to the proximity is homophily, a measure of proximity between two subjects linked to their sharing of significant individual characteristics; homophily acts as a multiplier of the 
potential a given relationship has to transfer informations and of its capability to be used to exert pressures to influence other network actors (McPherson, Smith-Lovin, \& Cook, 2001).

Other researchers (Lorraine \& White, 1971, Brieger, Boorman \& Arabie, 1975, Fombrun, 1982) have focused on identifying individuals structurally equivalent, those actors sharing the same network relational characteristics, in a given egonetwork, the set comprising all direct or indirect relationships in a social network created starting from a specific actor.

\subsection{Hypotheses Development}

The theoretical framework has shown how the business can be seen as a complex system composed by several heterogeneous actors that are affected by the players' activities and the behavior (Freeman, 1984). Moreover, these players can help the organisations - or decide to hinder them - in achieving their goals. So, as highlighted by the prior literature, the enterprises are forced to use the relationship with other heterogeneous players in order to survive their day to day operations, to compete effectively in the business and to define their success strategies.

The stakeholder approach since its creation (Freeman, 1984; Rowley, 1997) has focused on the need to overcome a narrow vision of strategy definition as a deterministic process focused on the organization and only some limited business objectives in order to fully comprehend and assess the effects of the whole network of relationship on those same decision-making processes.

This approach may benefit from using tools of systems theory and network theory (Granovetter, 1973; Tichy, Tushman \& Fombrun, 1979) to determine causes of these effects using two different perspectives (Borgatti \& Foster, 2003): the first perspective identifies the influence of a given stakeholders as a consequence of its position within enterprise social network (Fombrun, 1982; Burt, 1992; Rowley, 2000; Lin, 2001), the second value as stronger the effects from homophilous relationships, namely those relationships between similar actors (McPherson \& Smith-Lovin, 1987).

Following the first approach of Network Theory, a stakeholder ability to affect decisions making processes of another actor in the social network is related to the specific network configuration that gives him a more or less central role in governing resources and / or information flows and has effects not only on social actors that are in direct contact with him, but also with those he can reach only through intermediaries. This element can be measured using and actor's measure of centrality (Shaw, 1954; Freeman, 1977; Wasserman \& Faust, 1994) bringing us to our first research hypothesis:

Hyp1: Actors with higher values of centrality in the social network will have a stronger impact on decision making processes.

The second approach, however, identify the source of an actor's potential to influence decision-making processes of another one from an existing proximity in their objectives. In this case, from sharing some of their main interests if not the whole social mission, it derives the focal point to exert pressure, obviously this leverage can be used only when there is a pre-existing direct connection with the company. Our second research hypothesis can be expressed as:

Hyp2: Actors already connected to the enterprise and protecting a more similar set of interests will have a stronger impact on decision making processes.

\section{Method}

\subsection{Sample and Variables}

In order to test our hypotheses, we have decided to focus our analysis on the social enterprises. These organizations, for their own nature, operating across the faded boundary between for profit and not for profit sectors, overcome having limited scarce resources dotation trough relationships with other several players, in order to reach their own social and economic goals. These organizations, while following the rules of the market to compete with traditional for-profit enterprises, are mainly focused on public interests or some other need in a specific social area (Price, 2008). Doherty, Haugh and Lyon (2014) highlight that "hybridity" is the main characteristic of social enterprises and use this term to explain the pursuit of their dual mission of financial sustainability and social purpose. These organizations have become points of reference for a bigger and bigger number of people to seek satisfaction for their own needs for which there was a market vacuum (Nyssens, 2007).

In particular, we have focused our attention on EMES European Research Network (Defourny, 2001, pp. 16-18), who provides a very structured definition of social enterprise, considering both economic and social aspects to determine if a given organization can (or cannot) be regarded as a social enterprise (Table 1). 
Economic factors identify those operations of a social enterprise that can be seen as made in order to protect, and warrant to other organizations, their independence from financiers and other external economic powers; they are usually linked to producing goods and / or providing services to people; related risks are managed with the cooperation of volunteers, associates, and employees, while the "social side" of the definition ask the initiative to seek solving a specific society need (or issue) using an organization coming out of a group of people organized to make decisions with a shared models where vote rights are not dependent on member's investments in the cooperative (financial or otherwise).

Table 1. Social enterprises characteristics (EMES Definition)

\begin{tabular}{ll}
\hline Economic & Social \\
\hline A continuous activity, producing and selling goods and/or services & An explicit aim to benefit the community \\
A high degree of autonomy & An initiative launched by a group of citizens \\
A significant level of economic risk & Decision-making power not based on capital ownership \\
A minimum amount of paid work & $\begin{array}{l}\text { A participatory nature, which involves the various parties affected } \\
\text { by the activity }\end{array}$ \\
& Limited profit distribution
\end{tabular}

Source. Adapted from Defourny, 2001, pp.16-18.

They are real entrepreneurial businesses (Dees, 1998; Paredo \& McLean, 2006) and often they are so similar to traditional for profit ones that Reis and Clohesy (2001) treat them as the mere consequence of applying normal good management rules to third sector; others (Dees, 1998; Paton, 2003; Harding, 2004) identify them as change agents who push social innovation through direct experience and knowledge they get trough a stable, intense, interaction with a given community. Dart (2004) notes that social enterprises, while keeping their social mission at the center of their actions, must continually renew their offer in order to identify new needs developing, or surfacing, in the communities where they operate.

Their core values are a lighthouse guiding their actions in a continuous research of cooperation opportunities in their own network of relationships and some authors (Mort Weerawardena \& Carnegie, 2006) observe that social enterprise management must balance interests of multiple stakeholders by disseminating best practices and communicating with social players sharing some of their characteristics that are trying to act for reaching similar objectives in order to create a relationship for supporting each other in their activities and to promote ideas diffusion (Brady \& Haugh, 2007).

We have chosen to narrow our empirical research on these organizations as their need to merge_business and social aspects in their operations is evidence that enterprises can successfully compete in the market without recurring to the separation fallacy.

\subsection{Subject Characteristics}

Among social enterprises we have focused our empirical research on a Fair-Trade Organization; these organizations are a class of social enterprises that operates a normal shop, or some other distribution players, needing to keep a keen eye on business administration and market orientation issues ${ }^{1}$. They assist communities in South of the World with a continuous stream of resources distributed through several medium-run contracts, from three to five years each, built upon the principles of mutual respect and not exploiting partners with lower bargaining power.

Fair-Trade Organizations are social enterprises, as for the EMES European Research Network definition (Defourny, 2001); they are, in fact, independent economic activities born out of the aggregation of a group of people; they work in the market selling goods produced working with raw materials (purchased following the principle of advance payment) from one or more cooperatives in the South of the World and sold in their shops using the "project-product" model, i.e. to help the consumer in easily identifying the specific social causes they are supporting with each single act of purchasing linking each product to the specific cause it is used to finance.

The shared decision making processes typical of these organizations helps to attract volunteers, but in order to carry on all the activities required in the various projects these organizations are interested on, they use several employees, both part-time and full-time as the specific project needs, and to survive in the market they have to 
compete with traditional "business only" companies beating them at their own game: getting a sustainable competitive advantage in the market.

Among these organizations, we studied the Social Cooperative E' Pappici (the bugs in Naples' dialect) a social enterprise based in Naples; it operates two world shops in the retail market and a regional warehouse for wholesale distribution of Fair-Trade products to the several hundreds of social organizations too small or inexperienced to manage a direct commercial relationship with national importers; the regional warehouse is the key element in our research because it facilitates this social cooperative in creating new relationships. A summary of E' Pappeci most important data is shown in table 2.

Table 2. Main data from our survey data

\begin{tabular}{l}
\hline Social Cooperative E' Pappici \\
\hline Operates in Naples' local area \\
It is a social cooperative since 2005 \\
Its members have been being active in the third sector since 1992 \\
Main Interests or Issues to care for: \\
Fair-Trade \\
Social Finance \\
Microbanking \\
Sensitization on several social issues (Trash Recycle, Public Water, Green Energy) \\
World-shops: 2 retailers (Vomero, Historical Center) \\
Wholesale: 1 warehouse (S. Giorgio near Naples)
\end{tabular}

Note. Our source data.

\subsection{Sampling Process and Descriptive Analysis}

Our empirical analysis was carried out using the tools of Social Network Analysis to represent first, and analyze later, the social network in which the social cooperative is embedded (Emirbayer \& Goodwin, 1994). Since our research topic are influences stakeholders in the Social Network can have on a specific social enterprise, we have chosen to build the egonetwork, the set of relationships the enterprise is embedded into, through snowballing sampling (Wasserman \& Faust, 1994).

This sampling methodology consists in identify, or in randomly select, a sample of subjects in direct relationship with a given social enterprise and ask them to supply contacts to some other social actors they think are relevant for carrying on the research process. In our research we have decided to ask each respondent for three new subjects they thought were relevant social actors for carrying on their activities. Thus, as indicated by Tichy, Tushman and Fombrun $(1979$, p. 510) we have made a reputational analysis of the social network built around E' Pappici; it is called reputational as it is based on perceptions that each subjects have of the network they are part of. In this particular case there are not specific network characteristics guiding us to a specific number of process reiterations we should make so we have decided to cut the process at the $3^{\text {rd }}$ degree, the one composed by those persons who are separated from the first, central, actor by not more than two intermediaries. The resulting social network will be used to take the measures needed to evaluate the two hypotheses of our research.

The first step in the sampling process was to stratify customers' population from recent years, the list of subjects was provided by the cooperative itself thanks to data extracted by their information system, in order to identify six classes of subjects: general third sectors organizations (GTSO), groups supported purchasing (GSP), institutions (INST), private sector operators (PSO), religious organizations (REL) and other players in the Fair-Trade niche (FTO).

As the social cooperative E' Pappici is a Fair-Trade Organization, we have ordered the six classes by revenues each subject had generated in the year preceding this study to highlight, since from the first steps of sampling process, the central role of the economic component of the management.

Sales variability was also used as a parameter in estimating the right sample size using the significance inverse formula for population with unknown variance (we choose an error margin of 16.66\%). Determined the relative size of the first-degree sample (24 subjects) we have randomly selected subjects to create a stratified sample (rounding errors has led us to select 27 actors in first degree component).

From this initial sample we used snowballing methodology administering a structured questionnaire to inquire 
each social actor for: the area of activity; their three main partners they collaborate with for carrying on their social activities; their social mission; and an assessment of his activities in accordance with the International Classification for Not for Profit Organizations (Note 2) through a 10-steps Likert scale. In this way, we reached a reference sample that is represented in table 3.

Table 3. Descriptive Statistics for the Stratified Sample

\begin{tabular}{lcccccccccccc}
\hline & \multicolumn{3}{c}{$\mathbf{1}^{\text {st }}$ Degree } & \multicolumn{3}{c}{$\mathbf{2}^{\text {nd }}$ Degree } & \multicolumn{3}{c}{$\mathbf{3}^{\text {rd }}$ Degree } & \multicolumn{3}{c}{ Full Egonetwork } \\
\cline { 2 - 13 } & $\mathbf{R}$ & NR & OoP & $\mathbf{R}$ & $\mathbf{N R}$ & OoP & $\mathbf{R}$ & NR & OoP & R & NR & OoP \\
& $(25)$ & $(3)$ & $(0)$ & $(42)$ & $(5)$ & $(9)$ & $(63)$ & $(12)$ & $(9)$ & $(130)$ & $(20)$ & $(15)$ \\
\hline GTSO & 2 & 0 & 0 & 16 & 2 & 0 & 26 & 7 & 1 & 44 & 9 & 1 \\
GSP & 2 & 1 & 0 & 1 & 0 & 0 & 3 & 0 & 0 & 6 & 1 & 0 \\
INST & 1 & 0 & 0 & 8 & 3 & 5 & 15 & 4 & 5 & 24 & 7 & 10 \\
FTO & 10 & 0 & 0 & 8 & 0 & 0 & 6 & 0 & 0 & 24 & 0 & 0 \\
REL & 5 & 0 & 0 & 5 & 0 & 0 & 5 & 0 & 0 & 15 & 0 & 0 \\
PSO & 5 & 2 & 0 & 4 & 0 & 4 & 8 & 1 & 4 & 17 & 3 & 4 \\
\hline
\end{tabular}

Notes. $\mathrm{R}=$ Interviewed Actor $-\mathrm{NR}=$ Actors we have not been able to interview $-\mathrm{OoP}=$ Actors that were indicated but that are out of the population's definition.

As can be seen from data in the table, the egonetwork shows a great variety of actors and, in spite of half the sample being composed by third sector players, including general third sector organizations and other fair-trade organizations, the other half saw a good percentage of institutional players (25\%) and private $(12.2 \%)$. The sampling process was completed with a non-response rate equal to $13.33 \%$ (we have reached 130 nodes out of 150). Some nodes have referred partners that where or too generic or that could not be linked to the social economy, so they where left out, considering them in the sample lead us to a response rate of $78.79 \%$

To understand these actors' scale of operations and their ability to develop awareness in the local area they operate into we have chosen to use the number of collaborators (the sum of volunteers, employees and members) has as a proxy for the organization dimension. As appears clearly from analyzing sample data, summarized in table 4, and focusing on the relative dimension of mean and standard deviation the sample can be considered anything but uniform. Analyzing the sample Range of the sample as a whole (39 999) and its relationship with interquartile range, which is 100 time lower (41), it follows that the greater data dispersion is linked to the most external data. The analysis of the values shows a crystal-clear case of positive asymmetry.

Table 4. Number of employees, volunteers and associates

\begin{tabular}{lccccccc}
\hline & Mean & sd & Min & Q1 & Q2 & Q3 & Max \\
$(392.233)$ & $(3711.07)$ & $(1)$ & $(9)$ & $(20)$ & $(50)$ & $(40000)$ \\
\hline GTSO & 967.907 & 6094.25 & 3 & 10 & 20 & 51.5 & 40000 \\
GSP & 20.2 & 17.7680 & 3 & 13 & 15 & 20 & 50 \\
INST & 121.813 & 246.062 & 2 & 9 & 46,5 & 93.25 & 1000 \\
FTO & 27.375 & 26.1431 & 2 & 9.75 & 17 & 38.5 & 115 \\
REL & 70.3333 & 121.618 & 10 & 20 & 30 & 55 & 500 \\
PSO & 9 & 10.9164 & 1 & 3 & 3 & 10 & 35 \\
\hline
\end{tabular}

The social network described by the relationship identified through sampling process can be represented by a tree sociographic, a classic representation method for snowballing processes (Wassermann \& Faust, 1994), as shown in figure 1.

Using a circle sociographic, as for figure 2, it is clear that figure shows a higher density than what was expected. In fact, we have measured that on average each node have been referred as a preferred partner 1.4178 times (this has been calculated as the average number of indegrees in the sociographic), this value is more significant when we consider that the average number of partners given in the network were only 2.134 (calculated as the average number of outdegrees in the sociographic). 


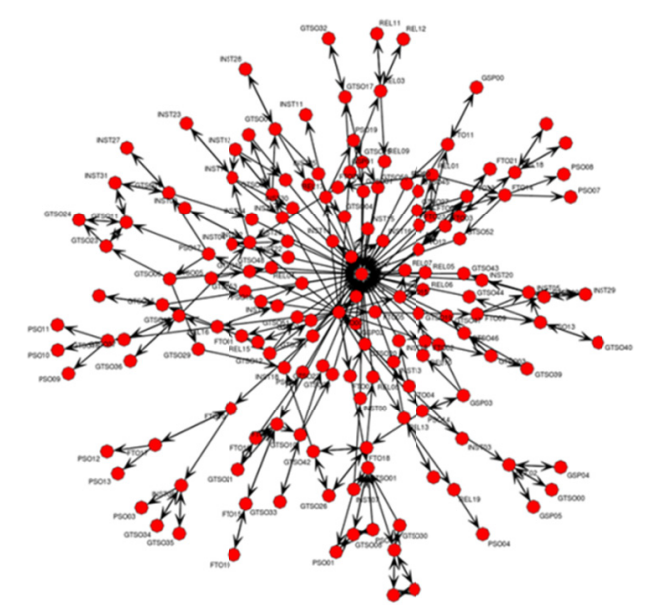

Figure 1. Sociographic of E' pappici social network

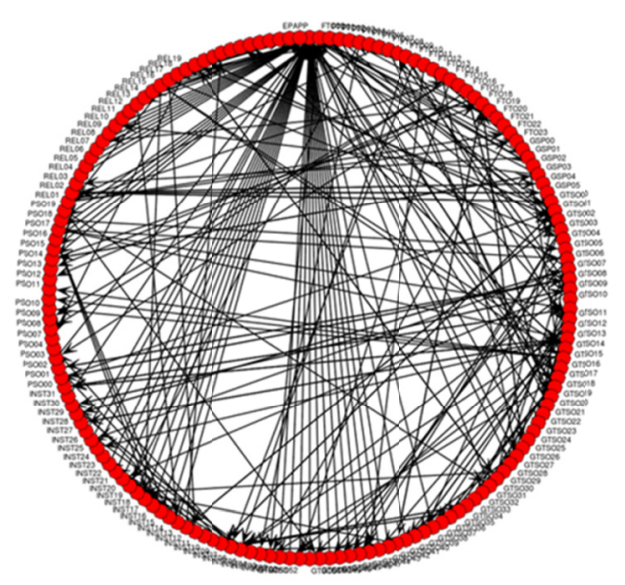

Figure 2. Circle Sociographic of E' pappici social network

\subsection{Research Analysis and Results}

Once defined the social network and we proceeded to check whether our assumptions are verified. Our first step has been to normalize all the evaluations given in the International Classification of No Profit Organizations part of the questionnaire in order to increase their homogeneity and to prepare data for being compared.

To check if first hypothesis is verified, we first had to identify to most central actors in the sample. To do this we have calculated an index of actor's centrality as the sum of indegree, the number a single actor has been referred as a meaningful partner, and outdegree, the number of meaningful partners the single actor has referred us. As we do not want to compare different social network, we did not need to normalize degree data. The average value found was 2.51 .

The nodes that had a sum of indegrees and outdegrees higher than the average (so 3 or more) were considered as the members of the more central class, the other were collected in the residual class.

The centrality index (sum of indegrees and outdegrees) was used as a weight in order to get a weighted average of International Classification of No Profit Organizations evaluations given in each of the two classes.

The second hypothesis asked to identify the elements of the homophiles class; we have highlighted this characteristic comparing the social missions provided by each single nodes with the key elements of the one given us by social cooperative "E' Pappici": sensitization to the territory, international cooperation, critical consumption, alternative lifestyles.

Each time a social mission explicitly mentioned one of these topics the related subject was awarded 1 point. The average value of the obtained scores has been 0.969 . 
Like first hypothesis, the individuals with a score higher than average were separated from the others and it was checked if they had a direct relationship with the social cooperative (as for the definition of homophily). At this point, we have calculated the weighted average of each class's evaluations represented in the International Classification of No Profit Organizations, using the given the relationship (ranging from 1 to 10), as perceived by each of the 34 subjects that composed the class, as the weighting factor. Again, the same procedure was repeated for the residual class.

The values listed above were then compared with the normalized assessment of E' Pappici's own activities using the International Classification of No Profit Organizations on a 10-steps Likert scale.

For each of the four area of activities identified by the Social Cooperative (Culture and Recreation, Social Services, Environment, International Cooperation) we have calculated the square difference for each class of nodes so to enhance differences between the proposition.

We have created an index of the class capability to influence the social cooperative decision-making processes, that we have called Influence Index Value, summing these differences and later making their own square roots to limit distortion effects from the previous squaring.

The obtained data are shown in table 5.

Table 5. Hypothesis' testing results

\begin{tabular}{|c|c|c|c|c|c|c|c|c|}
\hline \multirow{6}{*}{ 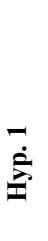 } & \multirow[b]{2}{*}{ E'Pappici } & \multicolumn{2}{|l|}{ \# } & \multirow{2}{*}{$\begin{array}{c}\mathbf{C} \& \mathbf{R} \\
0.37\end{array}$} & \multirow{2}{*}{$\begin{array}{c}\text { SS } \\
-1.4\end{array}$} & \multirow{2}{*}{$\begin{array}{l}\text { Env } \\
0.07\end{array}$} & \multirow{2}{*}{$\begin{array}{c}\text { IC } \\
0.95\end{array}$} & \multirow{2}{*}{$\begin{array}{c}\text { Influence } \\
\text { Index Value }\end{array}$} \\
\hline & & 1 & Value & & & & & \\
\hline & Central & 60 & WgtAvg & 0.03 & 0,28 & 0.43 & -0.04 & \\
\hline & & & SqDiff & 0.11 & 2.8 & 0.13 & 0.99 & 2.0075 \\
\hline & Periphery & 70 & WgtAvg & 0.22 & 0.2 & 0.28 & -0.1 & \\
\hline & & & SqDiff & 0.02 & 2.53 & 0.04 & 1.12 & 1.9261 \\
\hline \multirow{4}{*}{ 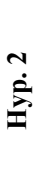 } & Homophilous & 34 & WgtAvg & -0.2 & -0.1 & 0.58 & 0.38 & \\
\hline & & & SqDiff & 0.32 & 1.68 & 0.26 & 0.33 & 1.6093 \\
\hline & Heterophilous & 96 & WgtAvg & 0.08 & 0.43 & 0.33 & 0.01 & \\
\hline & & & SqDiff & 0.08 & 3.35 & 0.07 & 0.89 & 2.0952 \\
\hline
\end{tabular}

Note. $\mathrm{C} \& \mathrm{R}=$ Culture and Recreation $-\mathrm{SS}=$ Social Services - Env $=$ Environment $-\mathrm{IC}=$ International Cooperation.

\section{Discussion}

Our research shows how the concept of homophily can adequately explain stakeholder dynamics in a network and his effects on decision-making processes of a social enterprise on the other side the analysis suggest that further investigations should be made in order to understand why the structure of network seems to be unable to explain influences on the central social cooperative actions.

We can start to discuss the results of the first hypotesis. Referring to the value corresponding to the selected classes (more central actors), we found that the Influence Index calculated on the residual class was lower (i.e. better) than the one in the main classes. This show how the first hypothesis should be substantially rejected. We must highlight, however, that the two Influence Index Values are almost similar, but this is still fairly against the expected results.

The second hypothesis, instead, seems satisfied with an Influence Index of the homophiles class significantly lower than the one built on the residual class. This value shows how this result is in accordance with the theory.

\section{Conclusions and Suggestions for Further Research}

The results of our analysis, compared with what is shown in the literature review, suggest a need to go deeper in this issue.

In fact, the results highlight it could be useful to further compare the values obtained of the structure of network and of homophily with a new model able to evaluate both perspectives at the same time. Indeed, it is believed that merging both aspects, we could understand if structural characteristics can be used to investigate if in the core of the homophiles nodes, there are players more strongly influencing the social enterprise. Moreover, the research process reveals that these subjects must weave a large number of relationships with many different classes of social actors. This aspect should be studied by focusing on Watts' provocation (2001), considering the aspects of key dynamic and evolutionary aspects of social network. 
Finally, we believe that results from this work may also have managerial implications. In our opinion it suggests that managers of social enterprises must gear their efforts towards those other social actors with whom they share at least part of social mission to maximize the possibility of influencing the decision-making processes and increasing the social enterprise chances to reach their social goals.

\section{References}

Ansoff, H. I. (1965). Corporate Strategy: An Analytical Approach to Business for Growth and Expansion. New York: McGraw-Hill. Retrieved from https://trove.nla.gov.au/work/10612688?q\&versionId=44954301

Barney, J. B. (2007). Gaining and sustaining competitive advantage (3rd ed). Upper Saddle River: Prentice-Hall. Retrieved from https://trove.nla.gov.au/version/42725671

Borgatti, S. P. (2005). The state of organizational social network research today, Department of Organization Studies. Boston College, Boston.

Borgatti, S. P., \& Foster P. C. (2003). The Network Paradigm in Organizational Research: A Review and Typology. Journal of Management 29(6), 991-1013. https://doi.org/10.1016/S0149-2063_03_00087-4

Borzaga, C., \& Defourny, J. (Eds.) (2001). The Emergence of Social Enterprise. London: Routledge.

Brady, A., \& Haugh, H. (2011). Social Entrepreneurship \& Networks. Journal of Finance and Management in Public Services, 6(3), 29-44. Retrieved from https://scholar.googleusercontent.com/scholar?q=cache:vCx61KeN5oQJ:scholar.google.com/+Brady,+A.+ $\% 26+$ Haugh,+ H. $+(2007) .+$ Social + Entrepreneurship $+\% 26+$ Networks\&hl=en\&as_sdt $=0,5 \& a s \_v i s=1$

Brieger, R. L., Boorman, S. A., \& Arabie, P. (1975). An algorithm for clustering relational data, with applications to social network analysis and comparison with multidimensional scaling. Journal of Mathematical Psychology, 12, 328-383. https://doi.org/10.1016/0022-2496(75)90028-0

Burns, T., \& Stalker, G. M. (1961). The management of innovation. London: Tavistock.

Burt, R. S. (1992). Structural Holes: The social structure of competition. Massachusetts: Harvard University Press.

Daft, R. L. (1998). Organization theory and design (6th ed.). Cincinnati: South-Western College Publishing.

Dart, R. (2004). The legitimacy of social enterprise. Non-profit Management \& Leadershp, 14(4), 411-424. https://doi.org/10.1002/nml.43

Day, G. S. (1994). The Capabilities of Market-Driven Organizations. Journal of Marketing, 58(4), 37-52. https://doi.org/10.2307/1251915

Day, G. S. (1999). Creating a Market-Driven Organization. Sloan Management Review, 41(1), 11-22. Retrieved from https://repository.upenn.edu/marketing_papers/402

Dees, J. G. (1998). Enterprising Nonprofits. Harvard Business Review Jen-Feb, 55-67. Retrieved from https://hbr.org/1998/01/enterprising-nonprofits

Defourny, J. (2001). From Third Sector to Social Enterprise. In C. Borzaga \& J. Defourny (Eds), The Emergence of Social Enterprise (pp. 1-28). London: Routledge.

Defourny, J., \& Nyssens, M. (2008). Social enterprise in Europe: recent trends and developments. Social Enterprise Journal, 4(3), 202-228. https://doi.org/10.1108/17508610810922703

Doherty, B., Haugh, H., \& Lyon, F. (2014). Social enterprises as hybrid organizations: A review and research agenda. International Journal of Management Reviews, 16(4), 417-436. https://doi.org/10.1111/ijmr.12028

Donaldson, T., \& Preston, L. E. (1995). The stakeholder theory of the corporation: Concepts, evidence, and implications. Academy of Management Review, 20(1), 65-91. https://doi.org/10.5465/amr.1995.9503271992

Drucker, P. (1974). Management: Tasks, Responsibilities and Practices. New York: Harper \& Row.

Dyer, J. H., \& Singh, H. (1998). The relational view: Cooperative strategy and sources of interorganizational competitive advantage. Academy of Management Review, 23(4), 660-679. https://doi.org/10.5465/amr.1998.1255632

Emirbayer, M., \& Goodwin, J. (1994). Network Analysis, Culture, and the Problem of Agency. American Journal of Sociology, 99(6), 1411-1454. https://doi.org/10.1086/230450

Fombrun, C. J. (1982). Strategies for Network Research in Organizations. Academy of Management Review, 7(2), 280-291. https://doi.org/10.5465/amr.1982.4285594 
Freeman, L. C. (1977). A Set of Measures of Centrality Based on Betweenness. Sociometry, 40(1), 35-41. https://doi.org/ 10.2307/3033543

Freeman, R. E. (1984). Strategic management: A stakeholder approach. Boston: Pitman.

Freeman, R. E., \& Evan, W. M. (1990). Corporate governance: A stakeholder interpretation. Journal of Behavioral Economics, 19, 337-359. https://doi.org/10.1016/0090-5720(90)90022-Y

Freeman, R. E., Harrison, J. S., Wicks, A. C., Parmar, B. L., \& De Colle, S. (2010). Stakeholder Theory: The State of the Art. Cambridge: Cambridge University Press. https://doi.org/10.1080/19416520.2010.495581

Frooman, J. (1999), Stakeholder influence strategies. Academy of Management Review, 24, 191-205. https://doi.org/10.2307/259074

Frooman, J. (2010). The issue network: Reshaping the stakeholder model. Canadian Journal of Administrative Sciences/Revue Canadienne des Sciences de l'Administration, 27(2), 161-173. https://doi.org/10.1002/cjas.150

Galaskiewicz, J. (1996). The 'new network analysis' and its application to organizational theory and behavior. In D. Iacobucci (Ed.), Networks in marketing (pp. 19-31). Thousand Oaks: Sage.

Granovetter, M. S. (1973). The Strength of Weak Ties. American Journal of Sociology, 78, 1360-1380. Retrieved from https://www.jstor.org/stable/2776392

Harding, R. (2004). Social Enterprise: The new economic engine? Business Strategy Review (Winter), 39-43. https://doi.org/10.1111/j.0955-6419.2004.00338.x

Hinna, L. (2002). Il Bilancio Sociale. Milano: Il Sole24Ore.

Kilduff, M., \& Krackhardt, D. (2017). Bringing the individual back in: A structural analysis of the internal market for reputation in organizations. Academy of Management Journal, 37(1), 87-108. https://doi.org/10.5465/256771

Kilduff, M., \& Tsai, W. (2003). Social Networks and Organizations. London: Sage Publication.

Kochan, T. A., \& Rubinstein, S. A. (2000). Toward a Stakeholder Theory of the Firm: The Saturn Partnership. Organization Science, 11(4), 367-386. https://doi.org/10.1287/orsc.11.4.367.14601

Langtry, B. (2015). Stakeholders and the moral responsibility of business. Business Ethics Quarterly, 4, 431-443. https://doi.org/10.2307/3857342

Lin, N. (1999). Building a Network Theory of Social Capital. Connections 22(1), 28-51. Retrieved from http://www.insna.org/PDF/Connections/v22/1999_I-1-4.pdf

Lin, N. (2001). Social Capital. A Theory of Social Structure and Action. New York: Cambridge University Press.

Lorraine, F. P., \& White, H. C. (1971). Structural equivalence of individuals in social networks. Journal of Mathematical Sociology 1, 49-80. https://doi.org/10.1080/0022250X.1971.9989788

McPherson, J. M., \& Smith-Lovin, L. (1987). Homophily in voluntary organizations. American Sociological Review 52, 370-379. https://doi.org/10.2307/2095356

McPherson, M., Smith-Lovin, L., \& Cook, J. M. (2001). Birds of a Feather: Homophily in Social Networks. Annual Review of Sociology, 27, 415-444. https://doi.org/10.1146/annurev.soc.27.1.415

Mitchell, R. K., Agle, B. R., \& Wood, D. J. (1997). Toward a Theory of Stakeholder Identification and Salience: defining the principle of who and What Really Counts. Academy of Management Review 22, 853-886. https://doi.org/10.5465/amr.1997.9711022105

Mort, G. S., Weerawardena, J., \& Carnegie, K. (2006). Social Entrepreneurship: towards conceptualization. International Journal of Nonprofit and Voluntary Sector Marketing, 8(1), 76-88. https://doi.org/10.1002/nvsm.202

Nyssens, M. (2007). Social Enterprise: at the crossroads of market, public policies and civil society. London: Routledge.

Paredo, A. M., \& McLean, M. (2006). Social Entrepreneurship: A critical review of the concept. Journal of World Business, 41, 56-65.

Paton, R. (2003). Managing and measuring Social Enterprises. London: Sage Publication.

Pfeffer, C., \& Salancik, G. (1978). The External Control of Organization. New York: Harper \& Row. 
Porter, M. E. (1980). Competitive Strategies. New York: The Free Press.

Porter, M. E., \& Kramer, M. R. (1999). Philanthropy's new agenda: Creating value. Harvard Business Review, 77, 121-130. Retrieved from https://www.nonprofitjourney.org/uploads/8/4/4/9/8449980/_philanthropys_new_agenda_creating_value.pd f

Price, M. (2008). Social Enterprise. What it is and why it matters? Vale of Glamorgan: Fflan ltd.

Reis, T. K., \& Clohesy, S. J. (2001). Unleashing new resources and entrepreneurship for the common good: A philanthropic renaissance. New Directions for Philanthropic Fundraising, (32), 109-144. https://doi.org/10.1002/pf.3206

Rowley, T. J. (1997). Moving beyond Dyadic Ties: A Network Theory of Stakeholder Influences. Academy of Management Review, 22(4), 887-910. https://doi.org/10.5465/amr.1997.9711022107

Rowley, T. J. (2000). Does Relational Context Matter? An Empirical Test of a Network Theory of Stakeholder Influences. In Logsdon, J. M., Wood, F. J. \& Benson, L. E. (Eds.), Research in Stakeholder Theory, 1997-1998: The Sloan Foundation Minigrant Project (pp. 21-35). Toronto: Clarkson Centre for Business Ethics.

Rowley, T. J., \& Moldoveanu, M. (2003). When Will Stakeholder Groups Act? An Interest- and Identity-Based Model of Stakeholder Group Mobilization. Academy of Management Review, 28(2), 204-219. https://doi.org/10.2307/30040709

Savage, G. T., Nix, T. W., Whitehead, C. J., \& Blair, J. D. (1991). Strategies for assessing and managing organizational stakeholders. The Executive, 5(2), 61-75. https://doi.org/10.5465/ame.1991.4274682

Salamon, L. M., \& Anheier, H. K. (1996). The emerging non-profit sector. Manchester: Manchester University Press.

Sciarelli, M., Tani, M., Landi, G., \& Papaluca, O. (2019). The Impact of Social Responsibility Disclosure on Corporate Financial Health: Evidences from Some Italian Public Companies. International Business Research, 12(3), 109-122. https://doi.org/10.5539/ibr.v12n3p109

Scott, J. (1991). Social Network Analysis: a handbook. London: Sage Publication.

Shaw, M. E. (1954). Group structure and the behavior of individuals in small groups. Journal of Psychology, 38, $139-149$

Smith, W. K., Besharov, M. L., Wessels, A. K., \& Chertok, M. (2012). A paradoxical leadership model for social entrepreneurs: Challenges, leadership skills, and pedagogical tools for managing social and commercial demands. Academy of Management Learning \& Education, 11(3), 463-478. https://doi.org/10.5465/amle.2011.0021

Sydow, J., \& Windeler, A. (1998). Organizing and evaluating inter-firm networks: A structurationist perspective on network processes and effectiveness. Organization Science, 9(3), 265-284. https://doi.org/10.1287/orsc.9.3.265

Tichy, N. M., Tushman, M., \& Fombrun, C. (1979). Social Network Analysis for Organizations. Academy of Management Review, 4(4), 507-519. https://doi.org/10.2307/257851

Wasserman, S., \& Faust, K. (1994). Social Network Analysis - Methods and Applications. Cambridge: Cambridge University Press.

Wasserman, S., \& Galaskiewicz, J. (1994). Advances in social network analysis: Research in the social and behavioral sciences. Thousand Oaks: Sage Publication.

Watts, A. (2001). A Dynamic Model of Network Formation. Games and Economic Behavior, 34(2), 331-341. https://doi.org/10.1006/game.2000.0803

Watts, D.J. (1999). Networks, Dynamics, and the Small-World Phenomenon. American Journal of Sociology, 105(2), 493-527. https://doi.org/10.1086/210318

Watts, D. J. (2004). Six Degrees: The Science of a Connected Age. New York: W. W. Norton \& Company.

Yunus, M. (2008). How social business can create a world without poverty. The Christian Science Monitor. Retrieved from http://www.onestreet.org/pdf/Social_Business_article_Yunus_CSM.pdf 


\section{Notes}

Note 1. A complete definition of Fair-Trade was agreed in December 2001 from the main networks of Fair-Trade: FLO, IFAT (now WFTO), EFTA and NEWS. Further details are available at www.fairtrade-advocacy.org.

Note 2. International Classification for Not-for Profit Organizations was developed initially under the Johns Hopkins Comparative Nonprofit Sector Project (Salamon \& Anheier, 1996) and proposes a subdivision of the activities of non-profit organizations in 11 areas of activity plus a residual area: Culture and Recreation, Education and Research, Health, Social Services, Environment, Development and Housing, Law, Advocacy and Politics; Philanthropic Intermediaries and Voluntarism Promotion, International Cooperation, Religion, Business and Professional Associations, Unions.

\section{Copyrights}

Copyright for this article is retained by the author(s), with first publication rights granted to the journal.

This is an open-access article distributed under the terms and conditions of the Creative Commons Attribution license (http://creativecommons.org/licenses/by/4.0/). 